\title{
"Designer Yeast": an Enantioselective Oxidizing Reagent for Organic Synthesis
}

\author{
M. Kayser ${ }^{\mathrm{a}}$, Gang Chen and Jon Stewart ${ }^{\mathrm{b}}$ \\ ${ }^{a}$ Department of Physical Sciences, University of New Brunswick, Saint John, NB E2L 4L5, Canada \\ Fax +1 (506) 648-5650; E-mail: kayser@ unbsj.ca \\ ${ }^{\mathrm{b}}$ Department of Chemistry, University of Florida, Gainesville, FL 32611, USA \\ Fax +1 (352) 846-2095; E-mail: jds2@chem.ufl.edu \\ Received 25 November 1998
}

\begin{abstract}
The new bioengineered oxidizing yeast is an efficient, enantioselective reagent for Baeyer-Villiger reactions of a variety of cyclic ketones. The successfully tested reactions are discussed and tabulated and the protocols for small scale oxidations are described.
\end{abstract}

Key words: Recombinant yeast, Baeyer-Villiger oxidation, biocatalysis, chiral lactones, ketones, sulfoxides

\section{Introduction}

Single-isomer chiral drugs and agricultural products are important targets and growing demand has led chemists in industries, fine chemical companies and university laboratories worldwide to search for new asymmetric methods, new chiral catalysts and new technologies for the preparation, separation and purification of optically pure compounds. As a result, the use of biocatalysts in syntheses has increased dramatically in recent years. For example, stable isolated enzymes such as lipases are employed in the preparation of optically pure amines and alcohols on a scale of 1000-metric-ton per year ${ }^{1}$. Where enzymes are impractical, due to lack of stability or the requirement for expensive cofactors, microorganisms are the biocatalyst of choice because they provide both the enzymes and the cofactors. The microorganism-catalyzed transformations, however, present problems such as competing enzymes, over-metabolism of the desired product and difficulties in handling, in the case of pathogenic organisms.

The use of baker's yeast to synthesize "chiral building blocks" for traditional chemical syntheses has been favored by organic chemists and it remains an area of active research ${ }^{2}$. Industrial production of trimegestone by yeastmediated reduction has also been reported ${ }^{3}$. The multitude of successful applications has also uncovered practical difficulties associated with the use of yeast as a chiral reducing agent, most of which arise from the presence of multiple enzymes with overlapping substrate specificities but differing enantio- and diastereoselectivities.

Recently, we reported a new and potentially general solution to these problems using common baker's yeast ( $\mathrm{Sac}$ charomyces cerevisiae) $)^{4}$. Using standard cloning techniques we express a synthetically useful enzyme in yeast, thus creating yeast with new catalytic abilities that can be used as the biocatalytic tool for asymmetric oxidations.

\section{Engineered Oxidizing Yeast}

The first engineered yeast was designed as a reagent for highly useful enantioselective oxidation reactions. Cyclohexanone monooxygenase (E.C. 1.14.13.22) was chosen because of its broad substrate specificity, high enantioselectivity and its potential as a synthetic reagent. Since its purification and initial characterization over twenty years $\mathrm{ago}^{5}$, this enzyme has been shown to catalyze oxidations of sulfides to sulfoxides and to carry out the asymmetric Baeyer-Villiger oxidations of a variety of cyclic and bicyclic ketones ${ }^{6}$. Despite these successful applications and the importance of the Baeyer-Villiger reaction ${ }^{7}$, neither purified cyclohexanone monooxygenase nor the parent organism Acinetobacter sp. NCIB 9871 have become adopted for general use in synthesis. This is most likely due to the fact that cell growth (Acinetobacter is class II pathogen) and enzyme isolation require biochemical expertise and specialized equipment not found in the typical organic laboratory. Moreover, the enzyme is relatively easily denatured and requires NADPH as a cofactor. Although NADPH regeneration technology is now more frequently employed ${ }^{8}$, the expense and the small scale of preparations make this method unappealing to most organic chemists. The relatively small amounts of enzyme available, either from cyclohexanone-grown Acinetobacter cells or from an engineered Escherichia coli strain ${ }^{9}$ contribute to the problem. Because CHMO is a very useful but difficult to access enzyme it is a perfect target for expression in yeast. To express cyclohexanone monooxygenase in baker's yeast, the CHMO gene was amplified from Acinetobacter chromosomal DNA by the polymerase chain reaction and cloned into an $S$. cerevisiae expression vector (plasmid). The resulting plasmid was introduced in a multi-copy form into the S. cerevisiae $15 \mathrm{C}$ laboratory strain to create the new oxidizing yeast capable of producing larger quantites of the enzyme. The details of the construction of the recombinant yeast strain are described in our recent paper [4a]. 
Two important characteristics of the engineered yeast should be pointed out. The new yeast expresses CHMO only when it is "switched on" by the addition of galactose to the reaction medium. When "switched on" the yeast produces relatively large quantities of the enzyme because plasmids carrying the CHMO gene are present in 10 to 12 copies per cell. As a result oxidations can outperform baker's yeast customary reduction reactions.

\section{Yeast Catalyzed Oxidations}

After initial tests demonstrating the ability of our recombinant oxidizing yeast to completely convert cyclohexanone and cyclopentanone to the corresponding lactones, we studied oxidations of 2- and 3-substituted cyclopentanones and 2, 3- and 4-substituted cyclohexanones ${ }^{10,11}$ and oxidations of sulfides to sulfoxides and sulfones ${ }^{(12)}$. These reactions were found to be frequently highly regioand enantioselective, particularly in the case of BaeyerVilliger oxidations of cyclohexanones, and confirmed the fact that the engineered yeast acts as a bioorganic enantioselective equivalent of peracids.

Although all reactions discussed here can be carried out in an organic laboratory without microbiological expertise and without specialized equipment, access to a fermenter can significantly facilitate the process, improve the yields and allow work on a larger scale.

\section{Biographical Sketches}
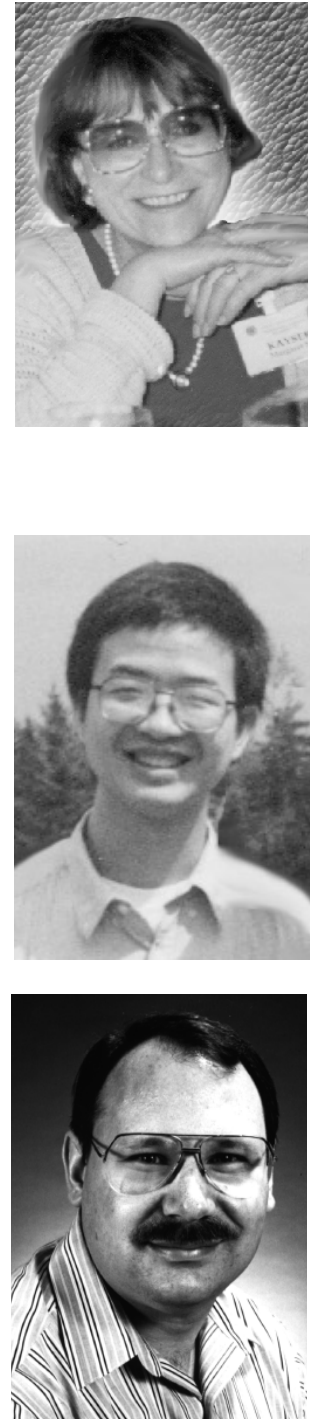

Margaret Kayser obtained a Ph.D. from University of Ottawa in 1979, where she worked on metal hydride reductions with Prof. Peter Morand. She pursued post doctoral research on the theoretical aspects of hydride reductions at Orsay and the Laboratory of J.-M Lehn in Strasbourg. After teaching at the University of Monc-

Gang Chen obtained Honors BSc at Peking University in 1995 . He is presently completing his PhD dissertation working with Margaret Kayser.

Jon Stewart received his B.S. and M.S. degrees from Bucknell University in 1986 and 1987, respectively. He then earned his Ph.D. from Cornell University in 1991 under the direction of Professor Bruce Ganem where he learned both organic chemistry and molecular biology while exploring structure-function relationships in one of the E. coli chorismate mutases. This was followed by postdoctoral ton and Mt. Allison University, she joined University of New Brunswick, Saint John in 1986, where she is full professor. Wittig reaction mechanisms have been her long-time research pursuit. She became interested in yeast catalyzed reactions in late eighties. In 1993, during a sabbatical leave in the lab of Prof. Stephen
Benkovic at Penn State University she designed her first "Baeyer-Villiger" yeast and with more than passive encouragement from Jon Stewart proceeded to clone the prototype. She is convinced that what one confirmed chemist can do (with yeast), another organic chemist can do. studies with Prof. Stephen Benkovic at Penn State University as a Helen Hay Whitney Fellow where he explored the mechanism of a catalytic antibody and was introduced to Margaret Kayser and the potential of enzymatic methods in organic synthesis. Since 1994, he has been an Assistant Professor of Chemistry at the University of Florida where his research has centered on the creation and application of "designer yeast", the re-engineering of antibody structures and the use of antibodies to recognize specific types of photodamaged DNA. Like his collaborator, he is convinced that molecular biology offers many attractive options for the organic chemist and he is committed to making these methods accessible to the non-specialist. 


\section{Baeyer-Villiger oxidations of cyclohexanones and cyclopentanones}

Prochiral, 4-alkyl substituted cyclohexanones are cleanly and enantioselectively converted to the corresponding caprolactones as long as the chain is 1 to 3 carbon atoms long (Table 1). Cyclohexanones substituted with longer carbon chains or with bulky groups are oxidized inefficiently, or not at $\mathrm{all}^{4}$. On the other hand, preliminary results indicate that 4-halosubstituted cyclohexanones are excellent substrates for the Baeyer-Villiger oxidizing yeast ${ }^{13}$. Racemic 2- and 3- substituted cyclopentanones and cyclohexanones were investigated $[4,10,11]$ and the results are presented in Tables 2-5. 2-Substituted cyclopentanones and cyclohexanones are kinetically resolved with $E$ values of 200 or better when the alkyl chains are ethyl or longer in the case of cyclohexanones, and butyl or longer in the case of cyclopentanones [10,11].

The enantiomer of 3-methyl and 3-ethylcyclohexanones were converted to different regioisomers. Optically pure (R)- and (S)-3-methyl cyclohexanones are available from (+)- and (-)-pulegone, respectively ${ }^{14}$. The (R)-enantiomer gave 6-alkyl lactone, while its antipode was converted to 4-alkyl lactone. The oxidations of racemic 3-methyl, 3ethyl, 3-propyl and 3-allylcyclopentanones exhibit similar behavior, but the optical purities of lactones produced are much lower ${ }^{11}$. In contrast, racemic 3 -substituted cyclohexanones with alkyl chain of 3 or more carbon atoms were oxidized to a single regioisomer. By interrupting the reaction at 50\% completion the 6-allyl, propyl and butyl2-oxepanones could be isolated with good to excellent e.e. values $^{(10)}$. For the corresponding series of cyclopentanones the chain had to be 4 carbon atoms or longer, and the enantioselectivities were lower ${ }^{11}$. In the latter case, therefore, the principal utility of the reaction lies in the exclusive formation of 5-alkyltetrahydropyran-2-ones, which are not readily accessible by standard chemical methods.

Table 1 Baeyer-Villiger Oxidations of 4-alkylcyclohexanone with $15 \mathrm{C}(\mathrm{pKR} 001)$

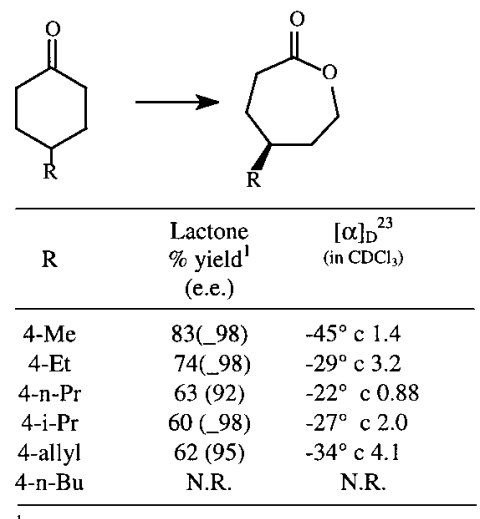

Table 2 Baeyer-Villiger Oxidations of 2-alkylcyclohexanone with $15 \mathrm{C}(\mathrm{pKR} 001)$

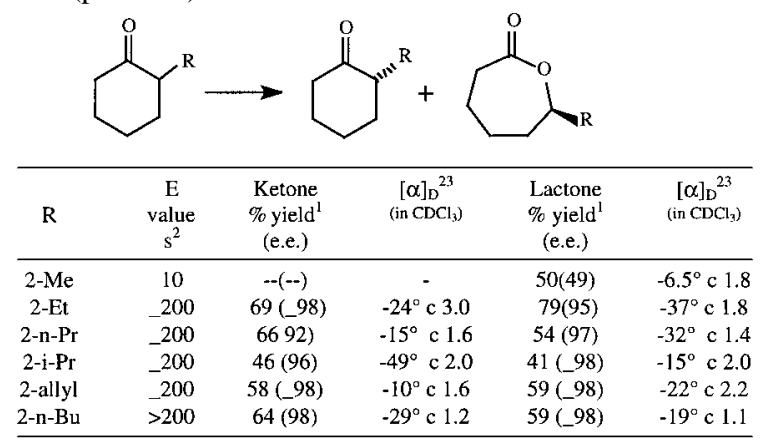

${ }^{1}$ Isolated, chromatographically purified yields. ${ }^{2}$ Enantioselectivity values.

Table 3 Baeyer-Villiger Oxidations of 2-alkylcyclopentanone with 15C (pKR001)

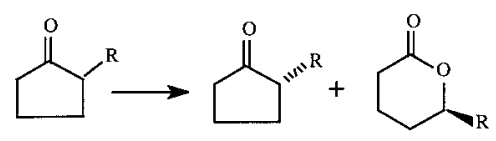

\begin{tabular}{|c|c|c|c|c|c|}
\hline $\mathbf{R}$ & $\begin{array}{c}E \\
\text { value } \\
\mathrm{s}^{2}\end{array}$ & $\begin{array}{l}\text { Ketone } \\
\% \text { yield } \\
(\% \text { c.e. })\end{array}$ & $\frac{[\alpha]_{D}^{23}}{\left(\text { in } \mathrm{CDCl}_{3}\right)}$ & $\begin{array}{l}\text { Lactone } \\
\% \text { yield } \\
\text { (\% e.e.) }\end{array}$ & $\underset{(i n]_{D}^{23}}{\left[\alpha l_{3}\right)}$ \\
\hline 2-Me & 3.6 & $34(44)$ & - & $36(32)$ & . \\
\hline 2-Et & 3.7 & $37(46)$ & - & $44(39)$ & - \\
\hline 2-Pr & 30 & $21(72)$ & $\begin{array}{l}-106^{\circ} \mathrm{c} \\
0.68\end{array}$ & $51(67)$ & $\begin{array}{l}-35.9^{\circ} \mathrm{c} \\
0.97\end{array}$ \\
\hline 2-allyl & 2.3 & $10(51)$ & $\begin{array}{l}-105^{\circ} \mathrm{c} \\
0.42\end{array}$ & $76(32)$ & $\begin{array}{l}-25.1^{\circ} \mathrm{C} \\
1.08\end{array}$ \\
\hline $2-\mathrm{Bu}$ & $>200$ & $32(>99)$ & $\begin{array}{l}-164 .^{\circ} \mathbf{c} \\
0.78\end{array}$ & $18(>99)$ & $\begin{array}{l}-48.4^{\circ} \mathrm{c} \\
0.83\end{array}$ \\
\hline $2-\operatorname{Hex}$ & $>200$ & $42(>99)$ & $\begin{array}{l}-112^{\circ} \mathrm{c} \\
0.70\end{array}$ & $32(>99)$ & $\begin{array}{l}-44.2^{\circ} \mathrm{c} \\
0.98\end{array}$ \\
\hline 2-Oct & $>200$ & $14(>99)$ & $\begin{array}{l}-113^{\circ} \mathrm{c} \\
0.46\end{array}$ & $25(>99)$ & $\begin{array}{l}-35.0^{\circ} \mathrm{c} \\
1.38\end{array}$ \\
\hline 2-Undec & $>200$ & $37(>99)$ & $-71^{\circ}$ c 2.19 & $39(>99)$ & $\begin{array}{l}-12.0^{\circ} \mathrm{c} \\
0.55\end{array}$ \\
\hline
\end{tabular}

${ }^{1}$ Isolated, chromatographically purified yields. ${ }^{2}$ Enantioselectivity values.

Table 4 Baeyer-Villiger Oxidations of 3-alkylcyclohexanone with $15 \mathrm{C}(\mathrm{pKR} 001)$

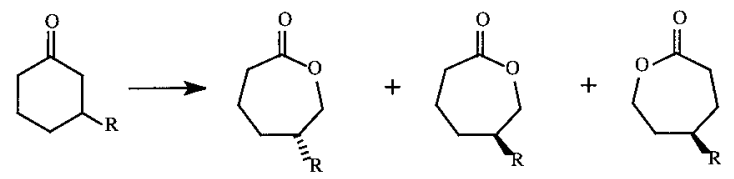

1(S) $\quad 1(\mathrm{R}) \quad 2$

\begin{tabular}{|c|c|c|c|c|c|c|c|}
\hline R & $\begin{array}{l}\text { Lacton } \\
\text { e } \mathbf{1}(\mathbf{S}) \\
\text { yield } \\
\%^{1} \\
\text { (e.e.\%) }\end{array}$ & $\begin{array}{c}{[\alpha]_{\mathrm{D}}} \\
(\text { in } \\
\left.\mathrm{CDC}_{3}\right)\end{array}$ & $\begin{array}{c}\text { Lactone } \\
\mathbf{1}(\mathbf{R}) \\
\text { yield } \\
\%^{1} \\
\text { (e.e.\%) }\end{array}$ & $\begin{array}{c}{[\alpha]_{\mathrm{D}}} \\
(\text { in } \\
\left.\mathrm{CDCl}_{3}\right)\end{array}$ & $\begin{array}{c}\text { Lacton } \\
\mathrm{e} \\
2 \\
\underset{1}{\text { yield } \%} \\
\text { (e.e.\%) }\end{array}$ & $\begin{array}{c}{[\alpha]_{\mathrm{D}}} \\
(\text { in } \\
\left.\mathrm{CDCl}_{3}\right)\end{array}$ & $\begin{array}{c}\text { Ratio } \\
\text { Lacton } \\
\text { cs } \\
1: 2\end{array}$ \\
\hline 3-Me & $\begin{array}{c}71 \\
(-98)\end{array}$ & $\begin{array}{l}-33^{\circ} \mathrm{C} \\
3.0\end{array}$ & --. & $\cdots$ & $\begin{array}{c}60 \\
(-98)\end{array}$ & $\begin{array}{l}-36^{\circ} \mathrm{c} \\
2.0\end{array}$ & \\
\hline 3 -Et & $18(70)$ & $\begin{array}{l}-26^{\circ} \mathrm{c} \\
2.1\end{array}$ & --- & $\cdots$ & $20(70)$ & $\begin{array}{l}-24^{\circ} \mathrm{c} \\
2.4\end{array}$ & \\
\hline $\begin{array}{l}3-n- \\
\mathrm{Pr}\end{array}$ & $\begin{array}{c}11 \\
(-98)\end{array}$ & $\begin{array}{l}-39^{\circ} \mathrm{c} \\
1.1\end{array}$ & $8.0(83)$ & $\begin{array}{l}+36^{\circ} \mathrm{c} \\
0.8\end{array}$ & --- & -- & $96: 2$ \\
\hline $3-\mathrm{i}-\mathrm{Pr}$ & N.R. & --- & --- & -- & --- & -- & --- \\
\hline $\begin{array}{c}3- \\
\text { Allyl }\end{array}$ & $15(97)$ & $\begin{array}{l}-25^{\circ} \mathrm{c} \\
1.5\end{array}$ & )$^{9.3\left(\_98\right.}$ & $\begin{array}{l}+30^{\circ} \mathrm{c} \\
0.9\end{array}$ & --- & -- & $93: 7$ \\
\hline 3-Bu & $37(56)$ & $\begin{array}{l}-23^{\circ} \mathrm{c} \\
5.6\end{array}$ & $11(84)$ & $\begin{array}{l}+27^{\circ} \mathrm{c} \\
1.1\end{array}$ & --- & -- & $98: 2$ \\
\hline
\end{tabular}

${ }^{1}$ Isolated, chromatographically purified yields 
Table 5 Baeyer-Villiger Oxidations of 2-alkylcyclopentanone with 15C (pKR001)

\begin{tabular}{|c|c|c|c|c|c|c|c|}
\hline & & $3(\mathrm{~S})$ & & $3(\mathbf{R})$ & & 4 & \\
\hline $\mathrm{R}$ & $\begin{array}{l}\text { Conv } \\
\text { ersio } \\
\text { n } \%^{2}\end{array}$ & $\begin{array}{l}\text { Ketone } \\
\text { yield\% } \\
\text { (e.e.\%) }\end{array}$ & $\begin{array}{c}{[\alpha]_{\mathrm{D}}{ }^{23}} \\
(\mathrm{in} \\
\left.\mathrm{CDCl}_{3}\right)\end{array}$ & $\begin{array}{l}\text { Lacton } \\
\text { es } \\
(3+4) \\
\underset{1}{\text { yield } \%}\end{array}$ & $\begin{array}{c}\text { Ratio } \\
\text { Lactone } \\
\text { s } \\
\mathbf{3}: \mathbf{4}\end{array}$ & $\begin{array}{c}\text { e.e. } \\
\% \\
3\end{array}$ & $\begin{array}{c}\text { e.e. } \\
\% \\
4\end{array}$ \\
\hline 3-Me & 100 & - & - & 95 & $13: 87$ & 9 & 36 \\
\hline $3-\mathrm{Et}$ & 86 & $10(19)$ & - & 80 & $20: 80$ & 33 & 19 \\
\hline 3-Pr & 53 & $27(13)$ & $\begin{array}{l}+18.2^{\circ} \mathrm{c} \\
2.5\end{array}$ & 44 & $83: 17$ & 33 & 60 \\
\hline $\begin{array}{c}3- \\
\text { Allyl }\end{array}$ & 43 & $551(--)$ & - & 43 & $44: 56$ & 23 & - \\
\hline 3-Bu & 44 & $44(25)$ & $\begin{array}{l}+15.8^{\circ} \mathrm{c} \\
1.4\end{array}$ & 34 & $\begin{array}{c}>99: \\
\quad 1\end{array}$ & 38 & - \\
\hline 3-Hex & 32 & $54(29)$ & $\begin{array}{l}+18.0^{\circ} \mathrm{c} \\
1.5\end{array}$ & 20 & $\begin{array}{c}>99: \\
\quad 1\end{array}$ & 60 & - \\
\hline 3-Oct & 31 & $44(8)$ & - & 19 & $>99: \_1$ & 16 & - \\
\hline Undec & 23 & $54(16)$ & - & 20 & $\begin{array}{c}>99: \\
-1\end{array}$ & - & - \\
\hline $\begin{array}{c}\text { 3- } \\
\text { Undec }\end{array}$ & 49 & $32(24)$ & - & 37 & $\begin{array}{c}>99: \\
-1\end{array}$ & 24 & - \\
\hline
\end{tabular}

${ }^{1}$ Isolated, chromatographically purified yields.

${ }^{2}$ Determined by gas chromatography.

\section{Oxidations of sulfides, dithiolanes and dithianes}

Since chiral sulfoxides are well known and useful building blocks in asymmetric synthesis ${ }^{15}$, and since CHMOcatalyzed oxidations of a variety of sulfur compounds were previously reported in the literature ${ }^{16}$, we tested the ability of our recombinant oxidizing yeast to perform these reactions ${ }^{(12)}$. The results indicate that yeast oxidations at sulfur are highly enantioselective and efficient for some, but not all, substrates. The problems arise when the host yeast strain's native oxidizing enzymes ${ }^{17}$ accept the same substrate as the CHMO enzyme, converting it to sulfoxide with the opposite enantioselectivity (or when applicable, diastereoselectivity). Another difficulty occurs when native oxidases, although not competitive in sulfide to sulfoxide oxidations, are proficient at the oxidation of sulfoxide to sulfone. Despite these shortcomings, results from studies of parallel oxidations with the purified CHMO indicate that, from a preparative perspective, yeast reactions are an attractive alternative.

\section{Future Prospects}

The success of the oxidizing yeast rests on its ability to give a single enantiomer. However, it is often desirable to have direct access to both antipodes. One of the challenges is to construct alternative yeast reagents that would be designed to accomplish that task. At present, the construction of new yeast reagents takes advantage of the availability of a wide variety of enzymes from bacterial and eukaryotic sources. Suitable enzymes, however, are not always readily available. To obtain yeast reagents tailored for specific synthetic needs we are planning to carry out directed evolution on some of the enzymes to adapt them for specific catalytic functions, such as access to the opposite enantiomers, as well as capacity to carry out other types of useful reactions. These "evolutionally-developed" enzymes will be overexpressed in the host yeast strains thus giving rise to true "designer yeasts".

\section{Experimental Protocols}

\section{Propagation, maintenance of the yeast reagent}

The yeast strain Saccharomyces cerevisiae 15C(pKR001) can be stored at $50 \mathrm{mg} / \mathrm{mL}$ in YPD containing $15 \%(\mathrm{v} / \mathrm{v})$ glycerol in a $-80^{\circ} \mathrm{C}$ freezer. The yeast is streaked directly from a frozen sample on a URA(-) plate and incubated at $30^{\circ} \mathrm{C}$ until colonies are $1-2 \mathrm{~mm}$ in size (yeast stock should be kept at low temperature at all times; vials that have been thawed should be discarded). Colonies from this plate are used for the propagation and preparation of the yeast reagent. The plate may be sealed with Parafilm and temporarily stored in a refrigerator at $4{ }^{\circ} \mathrm{C}$; however, colonies that have been on URA(-) plates for more than one week are known to start losing their activity.

A single colony is used to inoculate $50 \mathrm{~mL}$ YPD in a $250 \mathrm{~mL}$ baffled conical flask and is agitated at $30^{\circ}$, $250 \mathrm{rpm}$ overnight. At that time the culture should reach $\mathrm{OD}_{600}$ between $4-6$. The cells are harvested by centrifugation at $3000 \mathrm{x} g$ for $10 \mathrm{~min}$ at $0^{\circ}$. The yeast pellet is washed twice with TE and suspended in YPD containing 15\% glycerol at the concentration of approximately $50 \mathrm{mg} / \mathrm{mL}$. The resulting suspension is divided into $0.5 \mathrm{~mL}$ aliquots (sterile conditions are essential) and stored at $-80^{\circ}$.

\section{General protocol for preparation of yeast reagent}

YPD $(100 \mathrm{~mL})$ in a $250 \mathrm{~mL}$ baffled conical flask is inoculated with a single yeast colony. In order to increase the amount of yeast cells, 4 or 5 flasks may be prepared at the same time, each inoculated with a separate colony. The flasks are agitated on an orbital shaker at $30^{\circ} \mathrm{C}, 250 \mathrm{rpm}$ for 20-28h until the $\mathrm{OD}_{600}$ has reached 6-8. Cultures that have $\mathrm{OD}_{600}<6$ after $28 \mathrm{~h}$ should be discarded. The cultures are combined and cells are harvested by centrifugation at $3000 \times \mathrm{g}$ for $10 \mathrm{~min}$ at $0^{\circ} \mathrm{C}$. The yeast pellet is washed three times with TE buffer. After the final spin the yeast cells are suspended in $15 \%$ glycerol in TE at $0.2 \mathrm{~g} /$ $\mathrm{mL}$ wet mass, divided into $1 \mathrm{~mL}$ aliquots and frozen in a $-80^{\circ} \mathrm{C}$ freezer. These samples are ready for use in reactions.

A control reaction should be conducted for each batch of yeast. The reaction requires the use of $10 \mathrm{~mL}$ YPG, $10 \mu \mathrm{L}$ cyclohexanone and $0.1 \mathrm{~mL}$ yeast suspension (from frozen stock). After shaking at $30^{\circ} \mathrm{C}, 250 \mathrm{rpm}$ for overnight (12h), a conversion rate above $80 \%$ with no reduction and little metabolite present indicates acceptable activity of the yeast reagent. Batches that give conversion <95\% within $24 \mathrm{~h}$ or produce more than $3 \%$ of metabolites 
(mainly 2-phenylethanol) should be discarded. In our experience, the frozen stocks prepared as described above did not show significant loss of activity for at least 1 month.

\section{General procedure for yeast mediated oxidations}

The substrate is added to $100 \mathrm{~mL}$ YPG in a $250 \mathrm{~mL}$ baffled conical flask at the concentration of $10 \mathrm{mM}$. Frozen yeast reagent is thawed in a warm hand or in a $30^{\circ} \mathrm{C}$ circulating water bath. Defrosted yeast is added to the reaction flask (final concentration $2 \mathrm{mg} / \mathrm{mL}$ ) and the flask is agitated at $30^{\circ} \mathrm{C}, 250 \mathrm{rpm}$. The reaction may be monitored by withdrawing periodically $100 \mu \mathrm{L}$ of the medium and extracting each sample with an equal volume of EtOAc or $\mathrm{CH}_{2} \mathrm{Cl}_{2}$, by vigorously vortexing (30s), followed by centrifugation for $1 \mathrm{~min}$ at $7500 \mathrm{rpm}$. The organic layer is withdrawn and analyzed by GC, HPLC, or TLC. Ethyl benzoate or diethyl 1,2-dibenzoate $(50 \mathrm{ppm})$ may be used as an internal standard for the GC analyses.

When the reaction is finished, the medium is centrifuged. The yeast pellet re-suspended in $50 \mathrm{~mL}$ of distilled water is extracted twice with ethyl acetate $(100 \mathrm{~mL})$. The aqueous layer is saturated with $\mathrm{NaCl}$ and extracted with $200 \mathrm{~mL}$ of ethyl acetate in 3 or 4 portions. It is not advisable to directly extract the culture without removing the cells because of severe emulsion problems. Continuous liquid-liquid extraction, generally overnight, can also be used and this completely avoids the formation of emulsions. Combined extracts are extracted with brine and dried over anhydrous $\mathrm{Na}_{2} \mathrm{SO}_{4}$ or $\mathrm{MgSO}_{4}$. After removing the solvent on a rotatory evaporator, the residue is purified by flash chromatography on silica gel.

\section{Strategies for optimization of reaction conditions}

An alternative method, Method 2, may be used to prepare larger amounts of yeast. $10 \mathrm{~mL}$ YPD in a $50 \mathrm{~mL}$ conical flask is inoculated with a single colony of yeast. The flask is agitated on an orbital shaker at $30^{\circ} \mathrm{C}, 250 \mathrm{rpm}$ overnight. This culture is used to inoculate YPD (1:100 ratio by volume) in larger baffled conical flasks. Cell growth, harvesting and storage follow the protocols described in Method 1 .

Experience has shown that yeast cells briefly exposed to their preferred substrates show increased activities towards other substrates. The modification, Method 3, is based on the above observation. 200mL YPD in a $500 \mathrm{~mL}$ baffled conical flask is inoculated with a single colony of yeast. The flask is agitated on an orbital shaker at $30^{\circ} \mathrm{C}$, 250rpm. When the $\mathrm{OD}_{600}$ of the growing yeast reaches 4.0 , usually within $24 \mathrm{~h}$, the cells are separated by centrifugation at $3000 \mathrm{x}$ g for $10 \mathrm{~min}$ at $0^{\circ} \mathrm{C}$ and the yeast pellet is transferred to a $500 \mathrm{~mL}$ baffled conical flask containing $200 \mathrm{~mL}$ YPG. Cyclohexanone $(20 \mu \mathrm{L})$ is added and the reaction is allowed to proceed for $3-4 \mathrm{~h}$ until $\mathrm{OD}_{600}$ is 6-8. The yeast is harvested and stored as described in Method 1. In general, Method 1 (the original protocol [4a]) and
Method 2 give yeast with moderate but consistent activities. Method 3 produces high-activity yeast, but in some cases an increased proportion of metabolites may also be generated during the reaction.

If substrate solubility or toxicity is a problem, it may be advantageous to include a stoichiometric amount of cyclodextrin $(\alpha-, \beta-$ or $\gamma-$, depending on the substrate) in order to form an inclusion complex that will increase the solubility and reduce the toxicity of the substrate. In this case, the substrate and cyclodextrin are shaken in YPG until a uniform dispersion is achieved before the yeast is added. Because of the formation of inclusion complexes, it is necessary to use a longer extraction time and a larger amount of solvent in order to achieve yields comparable to those obtained in the reactions that can be run without cyclodextrin. Reactions with cyclodextrin are not always advantageous. It has been observed that in some cases the inclusion complex precipitates and the results are even poorer. Lowering the substrate concentration or adding the substrate in small portions may be considered for these cases.

The cell density exerts a profound influence on the reactivity. High activity was observed during the growth phase of the yeast. When the cell density reaches saturation the activity levels off and then slowly starts to fall. At very high cell densities, reduction may become the predominant reaction. On the other hand, too low initial cell density is not advisable since yeast loses activity after a prolonged incubation period.

It has been observed that aeration is beneficial to the reactions. To ensure enough oxygen in the system, the culture medium should never occupy more than $1 / 3$ of the total volume of the flask. The reaction flask may be covered with permeable materials such as 4-6 layers of KimWipe to allow the exchange of air, instead of the more commonly used aluminum foil. The conical flasks used in the reactions should be baffled and the orbital shaker set to a slightly higher speed to help aeration of the culture. However, even with these changes, large scale reactions (exceed 1L) still suffer from diminished reactivity, presumably due to lower efficiency of agitation and starting material dispersion. For larger scale reactions a fermenter is advisable.

Sometimes it is advantageous to pre-incubate the yeast in YPG containing a small amount of cyclohexanone (3$5 \mathrm{~mol} \%$ of the substrate) for $2-3 \mathrm{~h}$ before adding the substrate (variation on Method 3).

\section{Media Preparation}

YPD: To prepare 1L of YPD: Bacto Peptone $(20 \mathrm{~g})$ and Bacto Yeast Extract (10g) are stirred in distilled water and diluted to $900 \mathrm{~mL}$. Glucose $(20 \mathrm{~g})$ is dissolved to make up $100 \mathrm{~mL}$ of solution. The two solutions are autoclaved at $250^{\circ} \mathrm{F}$ for $15 \mathrm{~min}$. separately and mixed when cooled.

YPG: Same as above, except galactose is substituted for glucose. 
TE: Tris(hydroxymethyl)aminomethane, free base, $(10 \mathrm{mM}, 1.21 \mathrm{~g})$ and EDTA, disodium ethylenediaminetetraacetate, $(1 \mathrm{mM}, 0.37 \mathrm{~g})$ is dissolved in distilled water to make up $900 \mathrm{~mL}$. The $\mathrm{pH}$ is adjusted to 7.5 and the solution is diluted to $1 \mathrm{~L}$ and autoclaved at $250^{\circ} \mathrm{F}$ for $15 \mathrm{~min}$.

URA(-) plates: Yeast nitrogen base without amino acids $(0.67 \%, 3.35 \mathrm{~g})$; Bacto Agar $(2 \%, 10 \mathrm{~g})$; L-Tryptophan $1 \mathrm{~mL}(1 \mathrm{~g} / 100 \mathrm{~mL})$; L-Histidine $1 \mathrm{~mL}(1 \mathrm{~g} / 100 \mathrm{~mL})$; L-Leucine $1.5 \mathrm{~mL}(1 \mathrm{~g} / 100 \mathrm{~mL})$ are diluted with distilled water to $450 \mathrm{~mL}$. Glucose $10 \mathrm{~g}$ is dissolved in distilled water to give $50 \mathrm{~mL}$ solution. The two solutions are autoclaved separately at $250^{\circ} \mathrm{F}$ for $15 \mathrm{~min}$. and mixed when still warm (approximately $50^{\circ} \mathrm{C}$ ) before pouring into petri dishes (makes 20 plates).

\section{Suppliers}

All products necessary for the preparation of media and plates can be purchased from Fisher Scientific. The cultures of recombinant "Baeyer-Villiger" yeast, although not commercially available, can be obtained from the authors.

\section{Acknowledgement}

MMK and JDS are in debt to Prof. Benkovic for allowing this project to become a reality. Cyclodextrin used in these studies was a generous gift from Cerestar Inc. The results presented in Tables 1-5 are reproduced with permission of J. Am. Chem. Soc. 1998, 120, 3541-3548 and J. Org. Chem. 1998, 63, 7103-7106. Copyright 1998 Am. Chem. Soc.

\section{References}

(1) Stinson, S.C. Chem. Eng. News, September 21, 1998, 83.

(2) Servi, S. Synthesis, 1990, 1-25; Csuk, R.; Glanzer, B. I., Chem. Rev. 1991, 91, 49-97.

(3) Crocq, V.; Masson, C.; Winter, J.; Richard, C.; Lemaitre, Q.; Lenay, J.; Vivat, M; Buendia, J.; Prat, D. Org. Process. Res. and Devel. 1997,1, 2-13.

(4) (a) Stewart, J. D.; Reed, K. W.; Kayser, M. M. J. Chem. Soc. Perkin Trans. 1 1996, 755-757; (b) Stewart, J. D.; Reed, K.
W.; Zhu, J.; Chen,G.; Kayser, M. M. J. Org. Chem. 1996, 61, $7652-7653$.

(5) Donoghue, N. A.; Norris, D. B.; Trudgill, P. W. Eur. J. Biochem. 1976, 63, 175-192.

(6) Review: Stewart, J. D. Curr. Org. Chem. 1997, 2, 211-232. Several groups investigated CHMO's potential for asymmetric synthesis, for example: Walsh, C. T.; Chen, Y.-C. J. Ang. Chem., Int. Ed. Engl. 1988, 27, 333-343; Taschner, M. J.; Black, D. J. J. Am. Chem. Soc. 1988, 110, 6892-6893; Abril, O.; Ryerson, C.C.; Walsh, C.T.; Whitesides, G.M. Bioorg Chem. 1989, 17, 41; Alphand, V.; Archelas, A.; Furstoss, R. Tetrahedron Lett. 1989, 3663-3664; Levitt, M.S.; Newton, R.F.; Roberts, S.M.; Willetts, A.J. J. Chem. Soc., Chem. Commun. 1990, 619; Konigsberg, K.; Alphand, V.; Furstoss, R.; Griengl, H. Tetrahedron Lett. 1991, 499; Alphand, V.; Furstoss, R. J. Org. Chem. 1992, 57, 1306-1309; Alphand, V.; Furstoss, R. Tetrahedron: Asymmetry 1992, 3, 379-382; Taschner, M. J.; Black, D. J.; Chen, Q.-Z. Tetrahedron: Asymmetry 1993, 4, 1387-1390; Alphand, V.; Furstoss, R.; PedragosaMoreau, S.; Roberts, S. M.; Willetts, A. J. J. Chem. Soc. Perkin Trans 1 1996, 1867-1872.

(7) Krow, G. R. Org. Reactions 1993, 43, 251-798.

(8) Rissom, S.; Schwarlinck, U.; Vogel, V.M.; Tishkov, V.I.; Kragle, U.Tetrahedron: Asymmetry 1997, 8, 2523-2526.

(9) Chen, Y.-C.J.; Peoples, O. P.; Walsh, C.T. J. Bacteriol. 1988, 170, 781-789.

(10) Stewart, J. D.; Reed, K. W.; Martinez, C. A.; Zhu, J.; Chen, G.; Kayser, M. M. J. Am. Chem. Soc. 1998, 120, 3541-3548.

(11) Kayser, M. M.; Chen, G.; Stewart, J. D. J. Org. Chem. 1998 , 63, 7103-7106.

(12) Kayser, M. M.; Chen, G.; Stewart, J. D. manuscript in preparation

(13) Kayser, M. M.; Chen, G.; manuscript in preparation.

(14) Eisenbroun, M.J. J. Am. Chem. Soc. 1955, 77, 3383-3384.

(15) Solladié, G. Synthesis, 1981, 185.

(16) Alphand, V.; Gaggero, N.; Colonna, S.; Pasta, P.; Furstoss, R. Tetrahedron 1997, 53, 9695-9706; Colonna, S.; Gaggero, N.; Pasta, P.; Ottolina, G. J. Chem. Soc., Chem. Commun. 1996, 2303-2307; Alphand, V.; Gaggero, N.; Colonna, S,; Furstoss, R. Tetrahedron Lett. 1996, 37, 6117-6120.

(17) Natural baker's yeast was shown to carry out oxidations at sulfur for certain sulfides. Beecher, J.; Richardson, P.; Roberts, S. M.; Willetts, A. Biotechnology Lett. 1995, 17, 1069-1074; Tang, J.; Brackenridge, I.; Roberts, S. M.; Beecher, J.; Willetts, A., Tetrahedron, 1995, 51, 13217. 